\title{
COVID-19 Pandemic Bayanihan Initiatives: The CapSU Experience and Future Education Directions
}

\author{
Ian B. Arcega*, Elmer M. Albaladejo, Arnel Van Aleligay, Wennie F. Legario, \\ Ma. Dorothee J. Villarruz
}

Capiz State University, Philippines

*Corresponding author. Email: ibarcega@capsu.edu.ph

\begin{abstract}
The COVID-19 pandemic shifted the world's life, drastically changing humanity's economies, health, education, and futures. The pandemic united private and public organizations and individuals to work as one in the spirit of 'Bayanihan.' Bayanihan is the Filipino indigenous governance involving volunteerism in providing immediate and demand-driven solutions to peoples' problems societies in the light of development. The fear and uncertainty brought upon by the COVID-19 pandemic had caught the government and communities unprepared, calling for initiates to curb the crisis. The higher education systems were among those caught in this unprecedented crisis, thus required to develop different initiatives to provide an inclusive program for the welfare of its stakeholders. The Capiz State University was among the state universities that made bold initiatives at the onset of the pandemic with the 'CAPSU Save Program and Project Bulig' through the campus students' Supreme Council, faculty, staff, and alumni-then followed with other countermeasures to continue the institution's vision to provide quality service in education. Extensive planning and meetings were made to craft Capiz State University strategies and programs focused on inclusive and sustainable education, health, and safety congruent to the Commission on Higher Education and the Department of Education mandates. Future higher education plans, activities, and directions also included the key concepts of sustainable livelihood, providing safe and economic space for students' education but not limited to learning needs.
\end{abstract}

Keywords: COVID-19, Higher Education Initiatives, Bayanihan, Education future directions, Sustainable Development Goals

\section{INTRODUCTION}

The world has been shocked by the emergence of a novel coronavirus (COVID-19), spreading havoc worldwide. According to the World Health Organization (WHO), it is a global pandemic as the number of confirmed cases and associated fatalities continue to rise [5]. The ongoing health crisis and worldwide efforts to contain virus transmission are innovating and creating an immediate solution to lower fatalities. Still, it also impacted the global economy that introduced a drastic change and huge challenges for millions of peoples' lives millions of peoples' lives. International Labor Organization [6] estimates a significant reduction of work hours in the second quarter of 2020 worldwide, in the order of $10.5 \%$ or the equivalent of 305 million full-time workers, along with a higher year-end projection of unemployment.
Globally, the COVID-19 pandemic creates uncertainty in the lives of everyone. Thereby, the vulnerable sectors like the senior citizens, children, low-income earners, persons with a disability, youth, and indigenous peoples are the prime target of the impact of the COVID-19 pandemic on their health, safety, and welfare.

The government also faced the challenge of implementing response strategies to manage the transmission and overall wellbeing of the citizens. But also, the major problem that the government faced was the closure of various educational institutions across the globe, especially in developing countries like the Philippines.

President Rodrigo Roa Duterte mandated that the Commission on Higher Education (CHED) establish a mechanism to deliver education to students by shifting into new normal through flexible learning. 
Before these government mandates, higher education institutions were bombarded with different issues that needed immediate and inclusive solutions to the present scenario of higher education in the country.

Nonetheless, at the onset of the COVID-19 outbreak, different organizations like the various higher education institutions are called and ignite the spirit of Bayanihan or volunteerism as their initiatives of helping the Filipino people without hesitation.

\section{METHODOLOGY}

This descriptive-action research utilized information gathered from 30 volunteers, school officials, and LGU executives from Roxas City. The project implemented on the fabrication of PPEs and assistance to the students is from March to December 2020. Ethical considerations were strictly observed during the data collection.

\section{RESULTS AND DISCUSSIONS}

\subsection{COVID-19 Pandemic Bayanihan Initiatives: The CapSU Experience}

Capiz State University is one of the state universities in the country advocating the welfare and wellbeing of every Filipino. Natural calamities and even pandemics, the University adhere to the mandates of the government to help each other, be innovative to look for any means, and igniting the spirit of Bayanihan in the community.

During the COVID-19 outbreak, Capiz State University initiated the CapSU Save Program as the pandemic Bayanihan initiative. With strong support from the administration and achieving the vision of the University by delivering quality service and fulfilling its core values to the community. The program partnered with the Commission on Higher Education (CHED), faculty, staff, and other private individuals who extend their support to the University.

\subsection{Deployment of volunteers}

When the COVID-19 outbreak hit the country, the national government issued a strict implementation of lockdowns throughout the country, by this mandate limits the physical movement of every individual and closure of local and national economic activities.

The University Bayanihan initiatives called the volunteers to implement the CapSU Save Program by fabricating face masks, face shields, ear guards, and aerosol boxes. Also, the production of bread, alcohol, and other basic needs.
From February 2020 to August 2020, the total number of volunteers part of the program reach 3,800. The volunteers fabricate and distribute the relief goods and Personal Protective Equipment (PPE) to the frontliners, stranded students, senior citizens, and other marginalized community sectors.

Below are the numbers of the total goods and PPEs from March to August 2020.

\section{COVID-19 CAPSU Initiatives}

\begin{tabular}{|c|c|c|c|c|}
\hline 14 & Aerosol Boxes & 4162 & Kalabasa Pandesal & \\
\hline 541 & PPE Sets & 288 & Relief Goods & \\
\hline 230 & Ear Guards & 28456 & Food Pack & \\
\hline 230 & $\begin{array}{l}\text { Face Masks with } \\
\text { Shield }\end{array}$ & 230 & Face Masks & $\begin{array}{l}\text { Fruit Packs, Bottled } \\
\text { Water, Liquid Soap, } \\
\text { Alchol }\end{array}$ \\
\hline 230 & Fresh Cow's Milk & 11416 & Face Shields & \\
\hline
\end{tabular}

Figure 1. COVID-19 initiatives of Capiz State University.

\subsection{Characteristics of volunteers}

The volunteer's ages range from 20 to 50 years old. Due to lockdown, the real value of age is rooted in experiences. During the pandemic, volunteering is high in these ages [2].Mia

The majority of them were female. These include student leaders, teachers, engineers, police officers, local government officials, entrepreneurs, part-time workers, and private individuals. This scenario suggests that citizens' human capital and knowledge [1]. Older citizens are often more likely to collaborate with the public sector than their younger counterparts [4] and $75 \%$ of them were male, and $25 \%$ were female.

\subsection{Volunteers Reflections}

Further observation and random interviews pertain to the reflection of the volunteers during the pandemic. It showed volunteers' zeal to help the vulnerable groups and the desire to assist the frontliners, especially those at high risk of infecting the virus. Thus, the common answers from the volunteers if every individual has the courage, care, discipline, and love for each other the effects of the pandemic will be easy, and everyone is safe and secured. Above all, they have a high desire that the pandemic will end soon because they are also afraid of the welfare and wellbeing of their family and loved ones. 


\subsection{COVID-19 Pandemic Bayanihan Initiatives: The CapSU Future Education Directions}

The institution's responses and initiatives on the closure of schools and universities in February 2020 dramatically changed the country's educational landscape of higher education institutions. To mitigate the spread of the COVID-19 pandemic, the government mandates to develop an emergency education response as the future direction of the state universities. Hence, dealing with the sudden transition from face-to-face to remote teaching, the Commission on Higher Education (CHED) set guidelines for the University and colleges to organize online teaching and learning strategies. The University's roadmap to the future education directions is presented on the CapSU future education framework. This framework is unique in answering the needs of the students and other stakeholders by sustaining quality education in the new normal setup regardless of various factors and challenges that the University may address. The framework will pave the way for the University's clear and new education directions in achieving the vision to become a center of academic excellence delivering quality service to all.

\subsection{Support to Students' Welfare}

The University prepares plans for an inclusive delivery of service to the students. Strategies are developed on how to deliver holistic student development. The student welfare services ensure and promote students' wellbeing; the institutionalized activities in developing full potential for personal growth; and pro-active response on health the safety, including the marginalized group.

With this effort, the University prepares new normal support to students' approaches. Everyone is informed of the new guidelines and standards in delivering various services to achieve empowerment in sustaining a quality service to the stakeholders.

\subsection{New Normal Learning Strategies}

The University develops a Learning Continuity Plan. A plan that will guide the faculty to the new learning approaches that are need-driven instructions without compromising the quality of education.

Hence, the University adopts flexible learning wherein students can learn despite the pandemic and future problems that may hamper the educational system and process of the University.

\subsection{Enhancement of the Information Communicati-on Technology (ICT) Infrastructure}

The concern of the University is how to enhance and upgrade the ICT infrastructure because of the financial resources. An initiative is taken to solve the problem. Realignment of the budget prioritized the procurement of ICT infrastructures and sent proposals to a potential organization that can help the ICT enhancement and maximizes partnerships to the different Non-Governmental Organizations (NGOs).

\subsection{Human Resource Development Empowerment}

COVID-19 pandemic also affects the human resource of the University. Various factors are considered. The university invest resources in enhancing the faculty capability especially in providing the different venue for training on the new normal scheme. They were given access to webinars, scholarships, fellowships, and grants.

Whereby, faculty and staff were a partner and collaborated in achieving the new future education directions of the University. This effort will empower them to do their share in molding and shaping the future of the students.

\subsection{Partnerships and Collaborations}

Good governance in the University is in place. Will not materialize the success of the University without partnering and collaborating with different public and private institutions. Intangible and tangible resources of various institutions are a huge help to realize the vision of the University.

\subsection{Community Engagements}

At present, higher education executives have difficulty making important decisions. A coalescence of political, social, and economic pressures pushes higher education institutions to consider community resources and capability. In this pandemic, community engagement will foster diversity, partnerships, and the discovery of new learnings and experiences. This engagement will encompass new economic, social, educational, health, and quality of life societal concerns. Thus, community engagement will forge a new pathway to the higher education institution's future to realize the students' dream. 


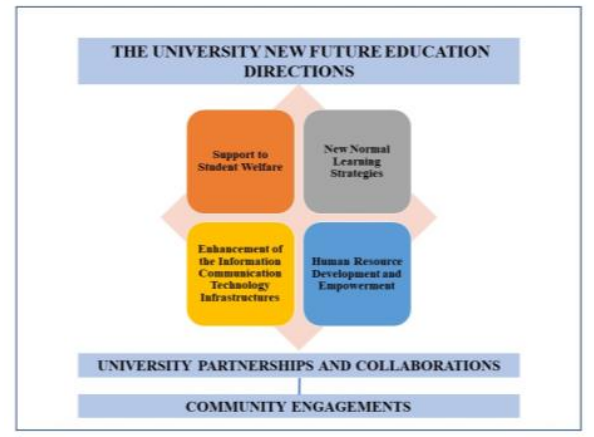

Figure 2. The University's new future education directions framework.

\section{CONCLUSION}

This article generates lessons from the experience of the COVID-19 pandemic in the Province of Capiz and Capiz State University. Volunteers' profiles and reflections come from diverse backgrounds and shapes, but one goal is to help and serve passionately. The Bayanihan spirit among Filipinos ignited without race, religion, economic status, and educational achievement to address the emerging crisis. Through Bayanihan, they are called as one in mobilizing everyone's efforts and resources.

With this, the new education future directions are increasingly relevant without compromising every Filipino's quality education. The pandemic calls on partnerships, collaboration, and community engagement in the realization of everyone's vision.

This article offers a springboard for future research to consider the potential of integrating reflections of volunteers, the Bayanihan spirit, and community engagements to meet societal needs.

\section{AUTHORS' CONTRIBUTIONS}

The authors contributed equally to the conduct and implementation of the project.

\section{ACKNOWLEDGMENTS}

The authors extend their gratitude to the Administration of the University, CHED, LGUs, Volunteers, Student Leaders, and Alumni who helped them through their donations.

\section{REFERENCES}

[1] Alford, J. (2009). Engaging public sector clients:From service-delivery to co-production. Basingstoke, UK: Palgrave Macmillan.
[2] Ganesh, S., \& McAllum, K. (2012). Volunteeringand professionalization: Trends in tension? Management Communication Quarterly, 26(1), 152-158

[3] Miao, Qing, Schwarz, S., Schwars, G., (2020). World Development 137 (2021) 105128. https://doi.org/10.1016/j.worlddev.2020.105128

[4] Parrado, S., Van Ryzin, G.G. Bovard, T., \& Loffler, E. (2013). Correlates of co-production: Evidence from a five-nation survey of citizens. International Public Management Journal. 16 (1), 85-112.

[5] World Health Organization. Coronavirus disease (COVID-2019) situation reports-95. Geneva: WHO; 2020 [Internet]. Available from: https://www.who.int/docs/default-source/ coronaviruse/situation-reports/20200424-sitrep95-covid-19. pdf?sfvrsn=e8065831_4 [cited 2020, May 11].

[6] United Nation (Internet) retrieved from https://www.un.org/sustainabledevelopment/sust ainable-development-goals/ on June 15, 2020 